\title{
Between global and local: Exploring regional food systems from the perspectives of four communities in the U.S. Northeast
}

\author{
Anne Palmer, ${ }^{\mathrm{a}, \mathrm{b}} *$ Raychel Santo, ${ }^{\mathrm{a}}$ Linda Berlin, ${ }^{\mathrm{c}, \mathrm{d}}$ Alessandro Bonanno, \\ Kate Clancy, ${ }^{\mathrm{a}, \mathrm{f}}$ Carol Giesecke, ${ }^{\mathrm{g}}$ C. Clare Hinrichs, ${ }^{\mathrm{h}}$ Ryan Lee, ${ }^{\mathrm{a}, \mathrm{b}}$ \\ Philip McNab, ${ }^{\text {a, }}$ and Sarah Rocker ${ }^{\mathrm{h}}$
}

Submitted April 14, 2017 / Revised July 20, September 26, and September 29, 2017 /

Accepted September 30, 2017 / Published online December 20, 2017

Citation: Palmer, A., Santo, R., Berlin, L., Bonanno, A., Clancy, K., Giesecke, C., Hinrichs, C. C., Lee, R., McNab, P., \& Rocker, S. (2017). Between global and local: Exploring regional food systems from the perspectives of four communities in the U.S. Northeast. Journal of Agriculture, Food Systems, and Community Development, 7(4), 187-205. http://dx.doi.org/10.5304/jafscd.2017.074.017

Copyright (C) 2017 by New Leaf Associates, Inc.

\begin{abstract}
Emphasis on local foods and local food systems has often meant that the importance of other scales goes unrecognized or underappreciated. While each scale has limitations, some food system experts now assert the benefits of the regional scale for its ability to foster a more sufficient, diverse, affordable, and resilient food system. This paper contributes to this debate by exploring people's

* Corresponding author: Anne Palmer; apalmer6@jhu.edu

${ }^{a}$ Center for a Livable Future, Department of Environmental Health \& Engineering, Johns Hopkins Bloomberg School of Public Health; 615 North Wolfe Street, W7010; Baltimore, MD 21205 USA.

${ }^{\mathrm{b}}$ Department of Health, Behavior and Society, Johns Hopkins Bloomberg School of Public Health; 624 North Broadway; Baltimore, MD 21205 USA.

${ }^{c}$ Department of Nutrition and Food Sciences, University of Vermont; 109 Carrigan Drive; Burlington, VT 05405 USA.

d Center for Sustainable Agriculture, University of Vermont; 109 Carrigan Drive; Burlington, VT 05405 USA.

e College of Agricultural Sciences, Colorado State University; 1200 Center Avenue Mall; Fort Collins, CO 80523 USA.
\end{abstract}

perceptions of regionally produced foods. Seven focus groups were conducted with a total of 51 participants across four locations in the U.S. Northeast. Topics discussed included the importance of knowing where food is sourced, how people described their region, personal connections to the region, globalization of food, importance of food origin, perceived benefits and drawbacks of regional foods, and the sense of efficacy and engagement involving food. While many participants were familiar with the concept of

\footnotetext{
${ }^{\mathrm{f}}$ Food systems consultant, University Park, MD 20782 USA.

g Department of Human Ecology, Delaware State University; 205A Ag Annex, 1200 North DuPont Highway; Dover, DE 19901 USA.

h Department of Agricultural Economics, Sociology \& Education, Pennsylvania State University; 111D Armsby Building; University Park, PA 16802 USA.

\section{Disclosure}

Financial support was provided under U.S. Department of Agriculture National Institute of Food and Agriculture (USDA NIFA) Agriculture and Food Research Initiative (AFRI) grant \#2011-68004-30057 (EFSNE).
} 
the local food system, their perceptions of the regional scale were weaker, less formed, and more divergent. These focus groups provide foundational insights into emerging consumer definitions and values related to regional food systems, which may help develop appropriately targeted messages to reinforce regional benefits.

\section{Keywords}

Northeast; Regional Food System; Local Food System; Consumer/Public Perceptions; Scale; Immigrants

\section{Introduction}

Most Americans consume food that is sourced through international, national, regional, and local supply chains. Given seasonal availability, production capacity, interest in food variety, and resiliency challenges, all sizes of scale are important in the food supply and play roles in meeting food needs and preferences of residents of any given locale. Since the mid-1990s, local food systems have attracted growing attention and support from many actors within the food system, including producers, consumers, wholesalers, and retailers, for reducing food miles, fostering community connections, and supporting local agricultural economies (Low et al., 2015; Martinez et al., 2010). However, attention to local food has often obscured the potential importance and contribution of other scales. While each scale has its limitations, the regional scale has gained attention because of recent claims among food system experts that it is critical for building more resilient food systems (Harris et al., 2016; Jensen, 2010; Ruhf \& Clancy, 2010). ${ }^{1}$ In this paper, the regional scale relevant to farming and food is considered to be smaller than the national scale but larger than a delimited local community.

While there has been increasing attention to consumer perceptions regarding local food (Adams \& Salois, 2010; Feldmann \& Hamm, 2015; McFadden, 2015) and to broader public percep-

\footnotetext{
${ }^{1}$ As Born \& Purcell (2006) argued in their pivotal article, "Avoiding the Local Trap," scale itself has no inherent merit; the contribution of a specific scale depends on how it serves a particular goal. If resilience is a central goal, the regional scale may be a particularly good means to that end.
}

tions of the U.S. food system (Bostrom, 2005), there has been little research to date examining consumer views of regional food systems specifically (Darby, Batte, Ernst, \& Roe, 2008; Hu, Batte, Woods, \& Ernst, 2012; Onozaka, Nurse, \& McFadden, 2010). This paper addresses this gap through an exploration of how residents perceive regionally produced foods in the Northeast U.S. Because few food shoppers distinguish between local and regional as food attributes, we also consider perceptions of how these scales overlap and relate to one another. Regions exist at various scales (e.g., Mid-Atlantic vs. Northeast) and are fluid (e.g., watershed, legislative districts) depending upon the issue under discussion (Ruhf \& Clancy, 2010). Geographic regions such as Appalachia and the Shenandoah Valley appreciate their own food culture, often generated from regional agricultural products (Hilchey, 2008; Hu et al., 2012).

This paper reports on research conducted as part of a larger U.S. Department of Agriculture National Institute of Food and Agriculture (USDA NIFA) project, Enhancing Food Security in the Northeast (EFSNE), which takes the 12 states from Maine to West Virginia, plus the District of Columbia, for its definition of the Northeast region. The EFSNE project aimed to assess whether greater reliance on regionally produced foods from the Northeast could improve food access for lowincome communities, while also benefiting farmers, food supply-chain firms, and others in the food system. The original plan for the five-year EFSNE project included conducting focus groups with Northeast shoppers in Years Two and Four. In both waves, these core EFSNE focus groups included limited discussion about regional food, in addition to other topics. Given the lackluster findings on regional food issues from the core focus groups, we decided to conduct seven supplemental focus groups that more deliberately framed the regional context. After gathering unprompted impressions, we provided our definitions of regional and local foods to enhance the discussion. This paper reports predominantly on these supplementary focus group findings; additionally, we discuss results from a question added to Year Four EFSNE store intercept-surveys which asked 
customers from which geographic areas they prefer to source their food.

\section{Literature Review}

The increasingly complex globalized commodity chains through which most food is now produced, distributed, and sold—undergirding a "placeless foodscape" (Ilbery \& Kneafsey, 2000, p. 319)—has been accompanied by growing efforts to re-spatialize the food system. Many of these initiatives concentrate on re-localizing food provenance under assumptions that such food is of superior quality, supports local economies, reconnects consumers and producers, and has a lower environmental footprint (e.g., through reducing the distance food travels from farm to plate) (Adams \& Salois, 2010; Low et al., 2015; McFadden, 2015; Mount, 2012). While messages emphasizing "local foods" and "buy local" resonate strongly with advocates and the public at large-especially compared to alternative value-based labeling schemes (Howard \& Allen, 2010)—what qualifies as "local" remains ambiguous and varies among consumers, producers, and retailers (Eriksen, 2013; McFadden, 2015). Most definitions reference geographical proximity, but this varies from anything grown (and/or processed) within 50 to 100 miles (80 to 161 kilometers) of where it is sold, to anything grown within the state (which may extend the radius to hundreds of miles in large states such as Texas and Alaska), province, or country (in the case of small European nations) (Eriksen, 2013). "Local" may also include an aspect of relational proximity, such as direct social relations between producer and consumer, and values of proximity, such as quality, freshness, traceability, and authenticity (Eriksen, 2013).

How the term "regional" relates to "local" adds complexity to such concepts, although foodsystem experts encourage advocates to adopt regional food system frameworks as well as local ones. Ruhf and Clancy (2010) argue that a regional framework, which is inclusive of local efforts but more than the sum of its parts, can maintain efficiencies of scale, thereby supplying a more significant proportion of regional food demand with greater volume, variety, and affordability than traditionally conceived "local" small-scale, niche, direct-to-consumer markets. Meanwhile, regional approaches may still provide producers more flexibility to practice socially, ecologically, and economically sustainable practices through product and market differentiation than producers striving for maximum volume at minimum costs (many of which are externalized). Several critical components of food system resilience and sustainability could be more optimally addressed at regional scales-including water resources, land use, topography, market access, and farm scale-than at local or global levels (Harris et al., 2016). Organizing social institutions, economic development, and ecosystem interactions at optimal sustainable scales is becoming increasingly important as we seek to mitigate and adapt to climate change, economic crises, and other environmental and socio-political concerns (Harris et al., 2016; Newman \& Dale, 2009).

Despite the unique attributes of regional approaches, local and regional food systems are often conflated or confused (Kneafsey, 2010; McFadden, 2015; Ruhf \& Clancy, 2010). The USDA, for instance, typically uses "local and regional food systems" or "local/regional food systems" as an umbrella term to encompass direct and specialty marketing; farm-to-school; food business, processing, and hub infrastructure; and community food project initiatives (Low et al., 2015). The Federal Reserve follows a similar convention (Dumont et al., 2017). Many academics as well oscillate between the two terms without a clear distinction (Kneafsey, 2010).

Some have also noted the importance of differentiating between "regional foods" and "regional food systems or networks" (Kneafsey, 2010). "Regional foods" refer to foods whose qualities are associated with biophysical, cultural, and socio-political elements of a specific geographic area. They are often emboldened by geographical indication (GI) certifications, such as the European Union Protected Designation of Origin (PDO), Protected Geographical Indication (PGI), and Traditional Specialty Guaranteed (TSG) system, which connect production and sometimes the processing and preparation of certain, mostly specialty, foods and drinks (e.g., ParmigianoReggiano cheese, Champagne, Welsh lamb) to specific territorial attributes. GI certification 
abounds more in Southern Europe, where foods and cuisines are more embedded in spatial contexts and cultural identity, as exemplified by the French concept of terroir (Barham, 2003), than in the relatively placeless foodscapes of countries such as the UK (Sonnino, 2007) and the U.S. (Barham, Bingen, \& Hinrichs, 2011). Nevertheless, British consumers also hold perceptions of "regional foods" that encompass food products and recipes produced in physical environments with specific climates, natural resources, and geomorphology, as well as linked to specific regional traditions, heritage, and socio-cultural practices (Kuznesof, Tregear, \& Moxey, 1997; Tregear, Arfini, Belletti, \& Marescotti, 2007).

While a few U.S. foods carry regional label protections (e.g., Vidalia onions, Tennessee whiskey), the salience of regional foods is largely absent in the American context. Some scholars have explored GI certifications in the U.S., butcontributing to the trend to conflate local and regional scales - have emphasized their potential to support local rather than regional ${ }^{2}$ foods (Giovannucci, Barham, \& Pirog, 2010). Only a few studies have differentiated between local and regional foods in U.S. consumer perceptions and preferences, but exploring these differences has not been the focus of their investigations (Hu et al., 2012; Onozaka et al., 2010).

The concept of "regional food systems or networks," 3 on the other hand, encompasses a system in which food production, processing, retail, and consumption are regionally organized and recognized as such by the actors involved. They may include regional foods such as the aforementioned GI specialty foods, but also other forms of produce, dairy and meat products, and even commodities (Kneafsey, 2010). The regional foodsystems approach advocated by Ruhf \& Clancy (2010) embodies such principles. So does the "agriculture of the middle" framework, which aims

2 This occurs despite the fact that the definition of GI that they cite from U.S. trademark law uses the term "regional" rather than "local."

3 Initially, "systems" was more prevalent in American/ Canadian terminology, whereas "networks" predominated in Western European agri-food literature (Hinrichs \& Charles, 2012); however, these distinctions have softened in the 2010s. to strengthen the vitality of midsize farms and, in some conceptualizations, midsize distributors and retailers in order to scale-up and increase consumer food access through food-system value chains (Clark \& Inwood, 2016; Kirschenmann, Stevenson, Buttel, Lyson, \& Duffy, 2008). Figure 1 displays a way to characterize the different intersecting scales of the food system and how they relate to one another.

Some of the basis for uncertainty and confusion about regional food may arise from the array of terms that have come into use in food system analyses. For example, some scholars use the term "foodshed," defined first by Hedden (1929) but brought to attention more recently by Kloppenburg, Hendrickson, and Stevenson (1996), who used it interchangeably with "region." This is particularly common in analyses of the potential of metropolitan regions to feed themselves (Horst \& Gaolach, 2014; Kremer \& Schreuder, 2012; Peters et al., 2008). However, others note that the foodshed concept has limited recognition by the broader public (Ruhf \& Clancy, 2010), and is used inaccurately in some cases. In addition, there is no consensus about what constitutes a foodshed, which makes it a difficult construct to implement.

An alternative concept, "bioregionalism," has arisen as a practical means to plan and design sustainable and resilient food systems. Unlike foodsheds, bioregions take into account the cultural identity of a place as well as its geography and its flora and fauna. For their project focused on southwest British Columbia, Harris and his colleagues employed a bioregional approach, which includes such landscape and social features as "terrestrial, marine, islands, watersheds, ecoregions, geopolitical boundaries, transport routes, and culture" (Harris et al., 2016, p. 12). Comparable to the fluidity of the regional construct, bioregions supersede fixed boundaries; the concept tends to necessitate experts consulting with community members to better understand what connects them to the food and agricultural landscape (Harris et al., 2016).

Scholars have employed different theories to investigate the diverse understandings and complexities of the definitions involving "local," "regional foods," and "regional food systems." Consumer perceptions of regional foods, and 


\section{Figure 1. Visualizing Different Scales of the Food System}

Retail venues, attributes, policies, and types of food are identified with the scale of the food system with which they are most closely associated. For instance, while some supermarkets sell "local" food, they are most likely selling food within a radius more typically defined as their region (and are generally operating through regional wholesalers, not through direct farm-to-supermarket interactions). Meanwhile, while free-trade agreements influence local-level policies, they concentrate on national and international supply chains.

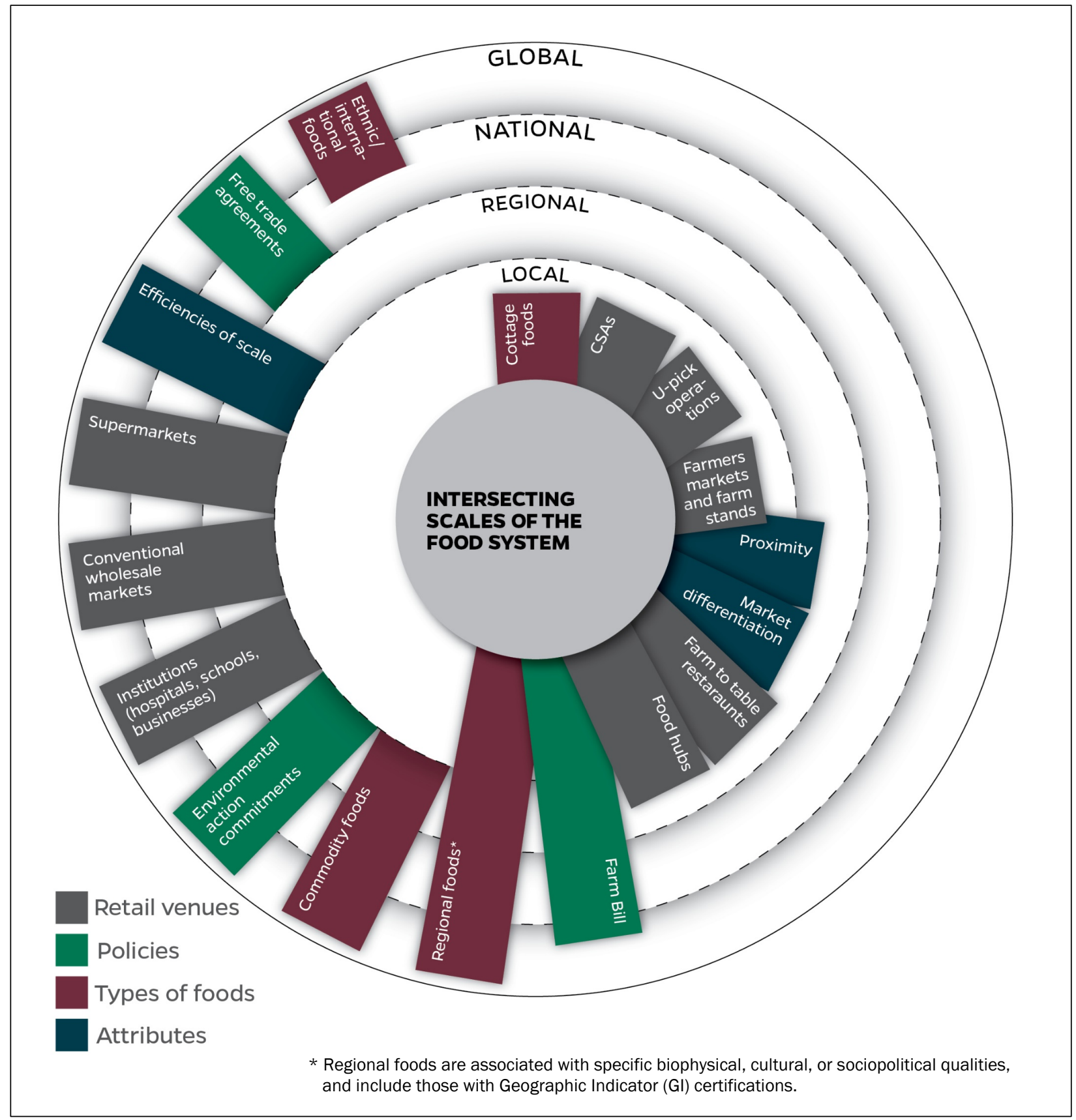

especially those differentiated through GI qualifications, are often analyzed through convention theory. Convention theory explores how partici- pants coordinate their economic, political, and social behaviors around common principles and qualities (e.g., market, industrial, civic, fame, 
domestic, inspired, environmental) rather than having their actions imposed upon them by a sweeping social order, a theoretical framework that is common in political economy approaches (Morgan, Marsden, \& Murdoch, 2006; Ponte, 2016). Meanwhile, the dynamic and sometimes contentious ${ }^{4}$ process of socially constructing scales to define "local" and "regional" food systems and their attributes echoes many concepts from "relational theories of place" (Sonnino, Marsden, \& Moragues-Faus, 2016). These emerging theories within larger social and geography theory assert the fluid, overlapping nature of regions, less territorially bound than the construct of regions evoked by conventional political and administrative jurisdictions (Amin, 2004; Jones, 2009; Massey, 2005). While the proximity associations of "local" are distinct from the more socio-environmental specificities of "place" (Hinrichs, 2016) and thus these are not directly comparable, discussions about defining "regional food systems" may benefit from engaging with the theories that explore similar dynamics in other fields.

Whatever proven and potential benefits follow from a focus on regional food systems, the popularity of local food surely begs the question as to the potential role for consumers in driving demand for any food system change. Does the public have a role in influencing demand for regionally produced food? If so, what information on product origin would influence consumer purchasing decisions? We know that regionally produced food is already present in regional supply chains (Clancy et al., 2017); is there any value in differentiating it from other food currently available, including "local" food? How can our knowledge about consumer expectations regarding local food inform our understanding of regional food attributes and governance (Mount, 2012)? And last, what do other stakeholders, such as distributors, producers, retailers, and policymakers, need to know about

${ }^{4}$ DuPuis and Goodman (2005) argue that open, continuous, "reflexive," and thus inherently political processes of defining the desired attributes associated with such scales are necessary to protect food system (local, in their article, but equally relevant to regional-level) reform initiatives from exclusivity and corporate co-optation, and instead to bring about the social justice and environmental outcomes they ostensibly espouse. regional food to support the necessary infrastructure investments to elevate its profile? The fundamentally spatial questions explored in this paper have important implications for improving communication about food system (re)regionalization among policymakers and other stakeholders and for clarifying promising interventions.

\section{Methods}

The EFSNE project included two rounds of focus groups that broadly assessed community members' thoughts and experiences related to food in their communities. The focus group objective was to discuss community perspectives on purchasing and consumption issues that covered the scope of the project; thus, results on regional themes were limited. To augment that work, additional qualitative data were collected with 51 participants from September to December 2013 in Baltimore, Maryland [referred to as SE Balt $(n=7)$ and SW Balt $(n=7)$ ]; Jamaica Plain, Massachusetts [JP $(n=12)$ ]; Harrington [DE-Harr $(n=11)]$ and Milford, Delaware [DE-Mil $(n=3)$ ]; and Winooski [VT 1 $(n=3)]$ and Burlington, Vermont [VT $2(n=8)]$. In these seven supplemental focus groups, all but one of which were conducted in study sites that were also part of the larger EFSNE project, we sought to explore how the public thinks about regions in general as well as regional themes specifically related to food. The supplemental focus group discussions were inspired by the EFSNE project, but separately funded and conducted with staff support from EFSNE researchers using the EFSNE budget. Because several study sites in the EFSNE project have significant immigrant populations, three of the supplemental focus groups were composed entirely of immigrants, which were set up as part of the screening process to recruit participants.

We designed the discussion guide for the supplemental focus groups to elicit instinctive, unprompted reaction to the concept of region and participants' connection to it. Participants were also asked about the extent to which they cared about the source of their food, the region with which they identified, and the ways they felt connected to their region. To contextualize their opinions about local and regional food systems, we 
further explored participant perceptions of the global food system and their perceived agency to change the food system. Moderators then presented the notion of local foods as food sold through direct marketing efforts and/or foods grown in the same state in which they are sold (Martinez et al., 2010). Finally, moderators introduced the project definition of the Northeast region, the project goals, and what was meant specifically by local and regional food systems, in order to ascertain participants' perceived benefits and drawbacks of local and regional.

In addition to the focus groups, we also included results from one question (only included in Year Four) on the EFSNE customer store intercept-survey that explored consumer food sourcing preferences, differentiating among local, state, and regional scales. The survey also collected information on consumers' perceived barriers to purchasing healthy foods, their shopping habits, and their demographic characteristics (methods described in Bonanno, Chenarides, \& Lee, 2015).

\section{Participants}

The focus group sample consisted of 51 adult participants from seven focus groups. Unless otherwise noted, quotes throughout the manuscript reflect one participant's observations. Participants were recruited through contacts at community organizations, flyers, and word of mouth. One focus group ( $n=7$ ) was conducted in Spanish and then transcribed into English. Otherwise, focus groups were conducted in English. Participant ages ranged from 25 to 93 years, and the mean age was 55 years. Seventy-eight percent of participants were female, and 37 percent of participants lived in households with children. Thirty-two percent of participants had completed elementary school or some high school; 28 percent completed high school; 22 percent completed some college or received a vocational or technical degree; and 18 percent received a four-year college degree. Thirtytwo percent of the participants reported having some form of diet-related chronic disease, and 57 percent participated in federal food or nutrition assistance program.

One thousand and sixty-one $(1,061)$ shoppers were included in the analysis of the store intercept- surveys for the question related to food provenance. The average age and years of education for the sample were 48 years and 13.25 years, respectively. Approximately 64 percent of respondents were female, and 38 percent of the respondents' households had children below five years of age. Approximately 43 percent participated in a federal food assistance program (SNAP, WIC, etc.). The respondents shopped, on average, 4.65 times per month and spent an average of approximately US $\$ 268$ on food purchases at the store per month. Sixty percent of them shopped at farmers markets, and approximately 19 percent lived in rural EFSNE locations (methods described in Bonanno, Chenarides, \& Lee, 2015).

\section{Data Collection}

EFSNE project staff moderated the focus group discussions, which averaged one hour in length and were conducted in private rooms at local community centers, organizations, or schools. Focus group guides were used to introduce topics, and probes were employed to obtain detail and stimulate discussion. Focus group participants completed demographic questionnaires that assessed personal characteristics and household composition. The Johns Hopkins Bloomberg School of Public Health Institutional Review Board approved the study.

Exit survey data were collected during face-toface interviews with shoppers exiting a store after completing their purchases at stores participating in the EFSNE project.

\section{Analysis}

Focus group discussions were digitally recorded and transcribed. Thematic analysis, in which transcripts were examined for patterns, was then performed using HyperRESEARCH (Braun \& Clarke, 2006). To begin the process, a team of four of the authors reads all transcripts to familiarize themselves with the data. An initial codebook was developed based on topics from the focus group guide. (This paper is also organized according to these topics.) Each transcript was double-coded, then authors developed specific sub-codes. We then met in pairs and as a team to reach consensus on the final codebook. Finally, each transcript was 
re-coded using the final codebook, before the team met again to reach consensus on all final codes. The data for the store intercept-surveys were analyzed with Microsoft Excel and STATA version 13.

\section{Results}

\section{Situating Regional}

To explore participant spatial understanding of their region and their connection to it, they were asked to identify their region and how they felt connected to it. Participants mentioned geographic regions such as East Coast, New England, and Mid-Atlantic; configurations of contiguous states such as Delmarva (Delaware/Maryland/Virginia) and Jersey/Delaware; and bioregions such as the Chesapeake. These responses resembled the findings for the EFSNE core focus groups conducted in 2014. Participants in multiple focus groups identified their region as the state in which they resided or a region within that state, such as the Eastern Shore of Maryland and the Northeast Kingdom of Vermont. One participant (SW Balt) noted, "They [people you meet] would ask "Where are you from?' not 'What region are you from?'," an observation confirming that "region" is not a regular conversational construct. Perhaps due to their experiences of having lived in a variety of places and moving across and engaging with multiple geographical scales, most immigrant participants gave their home country of origin first and then provided a response that included regions within the greater regions in the U.S., such as New England or the Mid-Atlantic. Thus, there were similarities but also a lack of consensus about what constituted a region.

Food and foodways factored prominently in what people associated with their personally defined region, as well as a specific climate and cultural, social, and recreational activities such as skiing, skating, fishing, boating, and festivals. Not surprisingly, seafood, particularly crabs, was mentioned a few times, as were milk, cheese, blueberries, apples, and watermelon. Participants in the EFSNE project core focus groups also associated certain produced and processed foods [e.g., cheesesteak, crabs, ramps (a type of onion), pepperoni rolls, apples] with their region. For some, states were associated with specific products: “...if you know anything about the Northeast, you know what is grown in each state" (SW Balt).

Focus groups with immigrants included more discussion about their ability to sustain native foodways in the U.S. One participant noted that she was pleased that produce that was available in her country was also available in the U.S. during the growing season, and looked forward to getting it from her country when the climate was too cold for growing it in the U.S. (SE Balt). Another immigrant explained that community connections helped retain his food culture: "We are still living together as a community, and we meet people from our own background a lot, and we have been able to maintain that, also our food habits and other living practices" (VT1).

The lack of a strong, definitive regional food system identity or preference, especially in comparison to local foods, was also reflected by consumers surveyed in the store survey component of the EFSNE project. Using data from interceptsurveys conducted at the study stores, we inquired about the importance of from where food comes. Of those who indicated that to them where food comes from is very or somewhat important, we asked which geographic scale was most important to them (Table 1). Notably-perhaps given their

Table 1. Shopper Preference of From Where Food is Sourced

\begin{tabular}{lccccc}
\hline & $\begin{array}{c}\text { Within } 100 \text { miles } \\
(\mathbf{1 6 1} \mathrm{km})\end{array}$ & Within the state & $\begin{array}{c}\text { Within state and } \\
\text { neighboring state }\end{array}$ & Entire Northeast & Other \\
\hline Rural & $28 \%$ & $29 \%$ & $19 \%$ & $14 \%$ & $9 \%$ \\
\hline Non-rural & $36 \% * *$ & $26 \%$ & $8 \%$ & $12 \% *$ & $18 \% * *$ \\
\hline Total & $34 \%$ & $27 \%$ & $10 \%$ & $13 \%$ & $16 \%$ \\
\hline
\end{tabular}

* Statistically different at the $1 \%$ significance level. * * Statistically different at the $5 \%$ significance level 
relatively larger geographical experiences — rural shoppers had a larger radius of preference and were more likely to indicate preference for regional over local food sourcing compared to non-rural shoppers.

\section{Perceived Benefits and Drawbacks of Supporting Local and Regionally Produced Food}

To avoid conflating local and regional foods in the focus groups, the researchers provided a paragraph explaining the EFSNE project and the specific 12state geography (and the District of Columbia) that was used to configure the Northeast region for the project. Even with this deliberate prompt, it was difficult to determine if the regional construct was viewed as distinct from local. (This ambiguity was similar to what occurred with EFSNE core focus groups.) Most people answered using familiar localfood attributes such as higher quality, fresher quality, more local economic impact, and lower transportation costs. When prompted, a few mentioned the word region; however, even then, participants (and occasionally facilitators) still mostly discussed local food system features such as farmers markets, farm stands, and homegrown foods.

\section{Economy}

Supporting the local and regional economy (i.e., circulating money in the region, supporting local farmers/neighbors, and providing jobs) was reported as an important reason to purchase local and regional foods by many of the focus group participants. As one participant stated, "To support the people that grow these foods, so that they make some money as well. Because if they are coming all the way here to sell the food. Then we go there because it is good quality and fresh but also to support them" (JP). While there was no distinction in responses between local and regional for this question, some participants extrapolated economic benefits beyond helping the producer: "If we use products produced by farmers in this region, then the money is going to stay in this region, right?" (SE Balt). Such logic replicates the common assertion that local food helps to keep dollars within the local community.

\section{Quality}

While a few people expressed skepticism about whether the quality of local and regional foods was better, most participants discussed how local and regional foods are fresher and taste better than those shipped from across the country or overseas. Some noted that they believe these foods are healthier too, because of the higher number of nutrients, fewer preservatives, and fewer chemicals and/or contaminants. One participant noted: "...Yes, when they are from the region they are healthier because they have less chemicals and contaminants for your health" (JP).

Some immigrants noted that in their home countries (Bhutan and Mexico), they may have shopped daily and eaten more local food, if not actually grown in their own garden or home, that was picked immediately before cooking and/or serving and was of fresher quality. At least two immigrants mentioned that purchasing directly from local farms is common practice in their countries (SE Balt and VT1). In the core EFSNE focus groups, immigrants also mentioned the importance of accessing fresh and high-quality meat and prepared foods such as tortillas. They also stressed freshness, taste, and fewer contaminants as features of local and regional food.

Price

Participants diverged in their opinions comparing the prices of local and regional foods with food not identified as such. Most responses focused on the contrast between purchasing at a direct-market venue (e.g., farmers markets) and a traditional retail outlet (e.g., supermarkets), rather than responding to the regional-scale prompt. Some felt that it was logical for local foods to be less expensive: "It should also be cheaper, because you don't have to pay as much for trucking and all that" (DE-Harr). In SE Baltimore, many participants expressed similar views: "I wait until there is a farmers market until on Tuesday, because of the freshness and the prices, like I said [it] is more economical." Other participants in that focus group referenced this notion that farmers markets were cheaper, especially in comparison to supermarkets, which they felt changed their prices too often and offered poorer quality. 
On the other hand, most participants commented that local and regional foods were not cheaper. A participant stated: "No, [it] is not cheaper but [it] is worth it" and "Once a year it's good. Once a year won't hurt you"5 (JP). Another woman expressed exasperation, "You try to buy locally, and it's up the roof, and you can't" (VT2). Others in that group also stated that the only reason they bought local foods was because of coupons offered. ${ }^{6}$ Without the coupons, they felt the food was too expensive for them. One participant also noted that people place a higher value on local food: "So what I've discovered is that people from our communities here are willing to pay... two or three times more if they get local chicken" (VT1).

Given that cost was the most cited challenge in accessing healthy food in the core EFSNE focus groups, this deliberation about the price of local and regional foods was expected. Some conversations became more nuanced, as participants tried to figure out why local and regional foods would be more expensive, given the expectation that shorter transportation distances should lead to lower costs. One participant suggested that there would be additional labor costs associated with more locally harvested fruits and vegetables compared to harvesting commodity crops (VT2). Another woman described economies of scale and that restricting products to a regional market would cost more because companies could not have bigger markets (DE-Mil).

\section{Variety and Availability}

Many participants accurately noted that the Northeast region is limited in what can be grown, both in types of foods (e.g., citrus fruits, ethnic foods, and coffee) and in growing season. Both California and Florida were mentioned, in jest, as regions where participants wanted to live so as to access what they offer. Participants also expressed appreciation of global supply chains that provided

\footnotetext{
5 "Una vez al año no hace daño" is a popular saying in Spanish-speaking countries.

${ }^{6}$ They were referring to nutrition incentive coupons, which double the value of Supplementary Nutrition Assistance Benefits (also known as "food stamps").
}

access to a wider variety of foods-especially culturally important foods-and to some produce that would otherwise only be available during the shorter growing season in the U.S. Others expressed concern that food needs to be imported, given U.S. capacity constraints.

In relation to variety and availability, a few participants discussed resiliency concerns such as farmland preservation, fuel costs, weather fluctuation, and carbon footprint. One person noted the importance of supporting local farmers and the economy to ensure that farmland is not lost and therefore unable to produce food (JP). Another participant described how certain products such as strawberries must come from different parts of the country to be available year-round. She was willing to be "more tolerant of that huge carbon footprint," especially for pleasures like eating chocolate-covered strawberries on Valentine's Day (DEMil). Her comment thus circles back to the previous discussions about seasonal availability.

In two of the immigrant groups (JP and VT1), participants acknowledged that there would never be enough food grown to feed the entire state: "I think [Vermont] is a state in which we have to resign yourself with what you get because here you can't harvest anything; then we have to accept everything that comes from other places... Whatever is harvested here in the farms during the summer is not enough to last until the next summer" (VT1). While most proponents of regional food systems do not posit regional self-sufficiency as the goal, these focus group conversations suggest the need to reinforce this point emphatically to preempt such concerns.

\section{Social}

Perhaps due to the predominance of direct marketing, participants frequently mentioned the assumed social attributes of local, but not regional foods. One woman stated after being prompted about benefits of purchasing regional foods: "And there's just a feel-good aspect. You know, if you can go to a farmers market and talk to the person who's actually raising the crop, it gives you a connection to your food that you can't get at Wal-Mart..." (DE-Mil). Some mentioned traditions and memories of going to a farmers market, roadside stand, 
or U-pick farm with their family, in childhood or with their children and grandchildren now. However, the regional connection to social attributes was not entirely absent from the discussions. One man discussed how Perdue had supported farmers in the Delmarva Peninsula by committing to purchasing all the grains the peninsula grows (DEHarr). Some in Harrington also brought up the marketing slogans used to influence consumer perceptions of the value of the local and regional food economy.

\section{Perceptions of Global Food System}

Two themes were most prominent in discussions of the global food system: the safety of imported foods, and the need or lack of imported foods to enhance supply and variety. With both themes, there were expressions of disagreement and uncertainty. There were also conspicuous differences across groups; the dissimilarities and similarities between immigrants and U.S.-born individuals were most notable.

In general, the debate about the safety of imported foods related to the thoroughness of U.S. inspections. Some participants suggested that inspections are adequate to protect consumer safety; for example, : "A lot of our vegetables come from Chile, and that is highly controlled by this country" (DE-Harr). Other participants, however, voiced concerns about imported foods due to the poor quality of inspections: "They need to do more better inspection because there's a lot of stuff that they import here, they be recalling a lot" (SW Balt).

Some conversations about the safety of imported food readily moved into discussion about the safety of domestically produced foods. One interesting but unusual remark reflected worries about the safety of foods grown in the United States: "But in the last few years, finding out what I do about how our food is grown and handled, it might be safer to buy imported foods than food that's raised right on my farm" (DE-Mil). On the other hand, several participants expressed confidence in the U.S. food supply as a whole, including domestically produced and imported foods, particularly relative to other countries; notably, a Nepali man appreciated the food hygiene practices in the U.S. compared to his home country (VT1).
Another topic of conversation was the food variety and supply possible because of imported foods. Several participants stated their preference for U.S.-grown foods: "If those food items can be grown here, that would be much better"(VT1). At least one participant questioned the need for imported foods at all: "I think the United States has enough resources here that we don't have to go out of the country to get our food. You know what I'm saying?" (SW Balt). Despite those statements, most people noted that origin of their food was not important to them and did not factor into their shopping decisions.

On the other hand, some participantsparticularly immigrants-indicated that imported foods were sometimes necessary JP: "Not all the things we need are grown here [in the United States]") or desired. The appeal of foods from participants' countries of origin was particularly strong (JP: “The products that we consume from other countries help the country that sells the product to progress"). In DE-Harr, participants remarked on the importance of global markets not just as a source of supply, but as a resource of demand, as when international markets can move a U.S.-produced product (e.g., chicken feet) for which there is not enough domestic demand. This notion of market interdependency was mentioned in another immigrant group as well: "You can find food from this country in my home country and foods from my home country here" (SE Balt).

\section{Ability to Influence Food Systems}

Although regional food systems were the focus of this study, we were also interested in participants' sense of efficacy and engagement with food. Participants were asked if they thought they could influence community-level food systems by working with their neighbors. Participants discussed as well their ability to have an influence on markets as consumers. The perspectives varied for both themes; however, most participants indicated that they perceived themselves as having a greater influence on neighbors than on businesses.

When asked about whether they felt that they had a voice in where their food comes from, most participants connected the economic principle of supply and demand to their ability to influence the 
food system. One person stated: "Supermarkets didn't sell Hispanic foods before and now you see that they sell yucca root, sweet potatoes, and those things; why? Because people asked for it" (JP). One participant remarked that demand affects producer decisions as well: "If we stop buying the products they grow, they won't want to plant for next year (SW Balt)."

Other participants doubted the influence of consumers acting individually, but they allowed for the possibility of collective change. In two focus groups (JP and SE Balt), participants made the connection that by purchasing food from their native countries, they were supporting the growers in their country of origin and ethnic food stores in their communities. In addition, they were sharing their food cultures with their neighbors.

Nevertheless, most participants conveyed the view that consumers have little influence. One participant noted, "I think we have influence, but we don't know how to use it on the owners of supermarkets. Because they are always going to get whatever is cheaper. They will buy in wholesale from a state where their products are at a lower price" (SW Balt). Another implied that national retailers are unlikely to consider a consumer perspective: "Think about Safeway. Think about Walmart. Think about Sam's Club. Where do they get their food from? Collectively, yeah, we might have a say in it, but they get their food from whomever they want to get it from" (SW Balt).

A few participants mentioned the absence of labels that would identify state or regional products, and their consequential disinclination to make point of origin a criterion for purchasing foods (DE-Mil, SW Balt). That said, even when that information was clearly available in the context of direct marketing initiatives-and participants stated that they enjoyed purchasing from farmers markets and other local venues-most acknowledged that they were not using origin as a filter in deciding what food to purchase. In contrast, participants did report using labels to determine freshness and expiration dates, of particular concern in lowincome neighborhoods where produce quality was perceived to be lower than in food stores in higherincome neighborhoods.

Regarding ability to influence neighbors, most participants were more optimistic. They affirmed the impacts of sharing knowledge, role-modeling the practice of gardening, and sharing foods and foodways. One immigrant participant from a South American country recounted that she invited her neighbor, an American, to one of her parties, and the neighbor became fond of pico de gallo (SE Balt).

\section{Discussion}

Inviting people to describe their perceptions about their regions, with an emphasis on regional and local food systems, yielded a variety of opinions and ideas. When we organized our findings thematically, we found that, as we anticipated, the concept of regional-especially compared to local, national, and global scales-is difficult for many people to explain and understand, and that people have conflicting views about the attributes of local and regional food systems, and the food system in general. We also found that, beyond our initial expectations, immigrants frequently articulated more nuanced perspectives on the different scales of the food system than non-immigrants.

At least within the project focus area, the Northeast U.S., the concept of region appears to be largely absent from the discourse of our study participants, while geopolitical boundaries provide a concrete frame of reference. As in the existing literature, participants discussed various scales in their notion of regional: multistate ("The region includes the five states that are right next to us" JP), state, multicounty ("Eastern Shore" DE-Harr), county ("Sussex County" DE-Mil), and bioregions ("We're more or less considered New Englanders" VT2).

The lack of regional identity in the Northeast may be a result of the shifting nature of what is defined as the Northeast. Our project (and the USDA) defined the Northeast as the 12 states from Maine to West Virginia, plus the District of Columbia. While New England is considered part of the Northeast, and always includes the same set of states, the Mid-Atlantic, also part of the Northeast, is more ambiguous. The U.S. Census Bureau considers the Mid-Atlantic to encompass NY, PA, and NJ (U.S. Department of Commerce, n.d.), whereas the U.S. Geological Survey references it as 
$\mathrm{MD}, \mathrm{DE}, \mathrm{VA}, \mathrm{WV}$, and parts of PA, NY, NJ, and $\mathrm{NC}$ that border the Chesapeake Bay (Greene, LaMotte, Cullinan, \& Smith, 2005). The USDA divides the country into larger regions, and even those are mutable depending upon the governmental program. The fluidity of regions is an acknowledged feature in regional food system frameworks and should be considered an asset, but may also lead to some confusion about definitions.

When participants were prompted to discuss how they perceived potential benefits and drawbacks of supporting their regional food system, local and regional were frequently conflated. For instance, participants immediately jumped to discussing the attributes of farmers markets, farm stands and other direct-to-consumer supply chains - and then considered what these activities translated to at regional scale. In addition, people articulated local attributes easily; however, they also acknowledged their confusion about what constitutes a "local product." For instance, some considered local foods to be only those from hyperlocal areas (i.e., within a radius smaller than their state) while others considered the local scale to include foods from a much larger distance or scale. This echoes the typical conflation of the two scales in both academic (Kneafsey, 2010) and grey (Low et al., 2015) literature. The global scale for food, on the other hand, was viewed favorably for variety and availability benefitting consumers but less favorably when the discussion turned to production methods, trade relations, and food safety.

Responses about attributes of different scales of the food system also revealed several misperceptions about the food system overall, such as lack of understanding about food safety procedures, production methods, and labeling. These results also were affirmed in the EFSNE project's core focus groups. This confusion and lack of transparency may help explain some of the overall distrust expressed of various actors within the food system such as retailers and government agencies.

Certain demographic groups responded to the concept of regional food systems with more ease and acceptance. For instance, the immigrant focus groups more easily situated themselves in a larger geographic region, perhaps due to the more global nature of their life experiences. By relocating to a new country, they may have a more firsthand perspective of how different geographical scales affect economic and social experiences. This may make them more attuned to possible distinctions between global, national, regional, and local supply chains. In one focus group (VT1), participants discussed opportunities for participating in food production themselves, raising animals and selling vegetables. Others mentioned purchasing food daily due to the growers' markets available to them when they lived in their home countries. Coming from countries with strong agrarian traditions may account for such perspectives. Meanwhile, rural consumers responding to the EFSNE store intercept-surveys indicated a greater preference for foods sourced from larger distances-within their state, state and neighboring states, and the Northeast- than their urban counterparts. This could be due to the nature of rural life, which necessitates traveling greater distances and perhaps makes them more attuned to the limitations of sourcing foods within a 100 -mile $(161-\mathrm{km})$ radius.

\section{Opportunities}

In the absence of robust empirical evidence on the importance of the regional scale, we outline several opportunities for strengthening the regional food system: increasing processing and value-added production, enhancing awareness of regional products, investing in infrastructure, and promoting agricultural models that link scales of production.

In these focus groups as well as in the core EFSNE focus groups, participants discussed constraints on eating regionally and seasonally but focused almost entirely on fresh foods. Limiting the conversation to fresh foods negates the role of processing foods grown in the region, which can be a viable means of supporting a larger regional food economy (Clancy et al., 2017). In addition, the EFSNE project found that many businesses involved in food processing and storage are in periurban centers. In Baltimore, for example, 61 percent of food processing and 75 percent of food storage businesses are in peri-urban zones (Saberi, 2016). These provide commerce and employment opportunities for the densely populated urban centers, and potentially another rationale for supporting the regional food system. Nevertheless, 
regionally grown or processed products are typically not distinguished or labeled by producers and processors and hence not recognized by shoppers as regional.

In fact, regional sourcing of both fresh and processed foods is already happening throughout the Northeast (Clancy et al., 2017) but not marketed in any uniform or well-recognized fashion to shoppers, especially compared to the emphasis on GI food products in Europe. While there may not be a need to devote significant resources to developing a regional food campaign identity, there may be many opportunities to increase consumer awareness of specific foods produced in northeastern regions, similar to the way that the rapid expansion of farmers markets has made local food suppliers visible (Gillespie, Hilchey, Hinrichs, \& Feenstra, 2007). Northeastern foods, many of which are sold on a large scale and at affordable prices through conventional supply chains, include lima beans from Delaware, mushrooms from Kennett Square, PA, cranberries from Cape Cod, MA, potatoes from Aroostook, ME, Concord grapes from Western NY and PA, and blueberries from Hammonton, NJ (Hilchey, 2008). Efforts to enhance awareness may be informed by the work of scholars who have begun to explore how to market regional products in other regions of the U.S. (Hu et al., 2012). Producers, producer cooperatives, distributors, and other intermediary stakeholders in the supply chain may all benefit from cleverly marketed consumer education efforts.

In addition, this proposed shift to support more regional food production would benefit from investment in infrastructure and value-added facilities, documentation of the value of regional food production, and development of better understanding of the supply chains operating within regions. Models such as small-scale grower cooperatives and food hubs that currently organize on a relatively local scale could benefit from collaborating with other cooperatives in a region through jointly pursuing infrastructure investment in valueadded processing, marketing regionally produced products, developing more joint education and organizational development training opportunities, and even allying with cooperatives in different regions and climates in order to maximize product variety (Hilchey, Gillespie, \& Henehan, 2006).

A large region with states that vary in size and population also presents opportunities for sharing infrastructure, distribution routes, environmental action commitments, and even social justice aspirations. For instance, large purchasers such as schools, hospitals, universities, and other institutions in the region could collaborate-as the Farm to Institution New England network does-to invest in important processing and transportation infrastructure, or to ask for similar environmental and social justice practices from their regional suppliers (e.g., through commitments pursued by the Real Food Challenge, Health Care Without Harm, and Center for Good Food Purchasing, all of which have region-specific staff organizers). Regional producers could also align themselves around social justice values to combat inequities of the national and global food system, such as the Federation of Southern Cooperatives explicitly pursuing economic, land, and housing justice for Black, Hispanic, Native American, and women farmers and ranchers (Zippert, 2014). Exploiting these opportunities through the adoption of a regional food-system framework may better supply the food needs of region inhabitants while also optimizing natural resource sustainability, land use planning, scale, economic development, biodiversity (Ruhf \& Clancy, 2010) and adaptation to climate change (Harris, Nixon, Newman, \& Mullinix, 2016).

While some of the participants in our focus groups seemed to understand the importance of the attributes of regional such as resiliency, there may not be enough comprehension yet to build a market. The more important audiences to promote and seek support for regionally produced and/or processed foods may be other actors in the food system. For instance, policymakers can allocate resources for infrastructure, growers and producers can aggregate products, distributors can optimize transportation routes, and academics can contribute with targeted, system-wide investigations such as the EFSNE project. Getting buy-in from these regional stakeholders promoting the value of regional supply chains will be necessary before any large-scale consumer education effort can be undertaken. 


\section{Conclusions}

The concept of region has not been adopted by food-system stakeholders, particularly in relation to food supply/provisioning chains, to the extent that regional approaches have been embraced in other sectors such as planning, community development, and natural resource management (McKinney \& Johnson, 2009). These potential benefits of a regional focus are increasingly important as we grapple with impending threats-i.e., the impact of climate change on crop yields, declining water availability, and extreme events (Thornton, Erickson, Herrero, \& Challinor, 2014)—which could be optimally addressed at a regional scale.

As the field of regional food systems, including efforts such as the Agriculture of the Middle initiative, continues to evolve, the evidence base supporting this work would benefit from an influx of resources. Midsize producers, particularly those practicing sustainable farming methods, may benefit from product differentiation; access to regional distributors, markets, and value chains; and overall regional efficiencies (Clark \& Inwood, 2016). Given any region's production limitations, regional food-system frameworks involve increasing the amount of food grown, processed, procured and consumed in a region to enhance regional selfreliance; they do not aim to create a fully selfsufficient region.

The results of this study revealed that selling the claims of regional food at the consumer level at this time might be premature for several reasons. First, the concept of regional compared to local food systems is ambiguous and amorphous. Without a clear sense of (or a strong evidence base to support) the unique benefits of regional food systems, it will be difficult to convey to consumers the regional food-system framework. Second, consumers may not actually be the most effective stakeholders to convert initially. As studies have shown, retailers and consumers do not define local food in the same way (Eriksen, 2013), so consumer demand does not necessarily translate into those products on store shelves. The fluidity of the regional scale, without a differentiated supply chain, would make demand similarly difficult to supply. Furthermore, our participants suggested that regional origin may not sway purchasing tendencies, given all that they consider when they are shopping. This type of food labeling demands significant consumer education and motivation to change purchasing patterns, as Grunert et al. (2014) found when examining sustainability labeling. Any marketing effort would need to be accompanied by a critical mass of regional supply chains, with clear communication about the benefits of regional food. Having stated this, some stores in the industry have been using the regional descriptor on in-store produce point-of-sale labels. This shift is in response to the co-opting of "local" by food marketers, which has led to consumers' skepticism that foods labeled local are really local (i.e., sourced from within their state or within 100-200 miles or 161$322 \mathrm{~km}$ ). Retailers have begun using the term "regional" to more transparently classify foods that are clearly beyond what consumers would think is local, but at least still support their regional economy. Seasonality also plays a role in what consumers define as "local" throughout the year (R. Stein, VP of Fresh Foods, Food Marketing Institute, personal communication, Nov. 28, 2017).

Other stakeholder groups could be more appropriate audiences for supporting the regional food system, especially as consumption patterns are also limited by the types of foods and purchasing opportunities available. Thus, changing whole systems of food provisioning at institutional levels may be more effective than targeting individuals through labeling schemes (Barnett, Clarke, Cloke, \& Malpass, 2005). For instance, due to increasing public interest, many schools, universities, hospitals, and governments have begun reforming their food procurement practices to support nearby producers and provide healthy, ecologically sustainable, fair, and humanely raised food. With their steady and significant demand, institutions are in an excellent position to support and expand regional food systems while helping build the evidence base for regional food sourcing (Fitch \& Santo, 2016). Meanwhile, regional food-system distribution and retail opportunities are greatest with midsized distribution and retail firms (Clark \& Inwood, 2016).

Future research could explore how other actors in the food chain, such as producers, distributors, retailers, and institutional procurement 
decision-makers who may have more power to influence and change supply chains, respond to the regional food system framework. Additionally, while some of the posited attributes—e.g., capacity to supply a larger proportion of demand while fostering natural resource sustainability, economic development, and diversity — of regional food system frameworks have been explored, further research to provide concrete evidence of its impacts is merited (Clancy et al., 2017).

This study is one of the first to attempt to differentiate consumer perceptions of regional and local food systems. Incorporating immigrant focus groups provided the analysis with a rich and unique perspective. Our study has also benefited from the collective learning that occurred with the EFSNE project over seven years among students, colleagues, store owners, and community leaders across the nine sites, eight universities, and USDA Agricultural Research Service (ARS) and Economic Research Service (ERS) staff.

This study has several limitations. As a qualitative investigation, the focus group results are not statistically generalizable and only represent the discussions we facilitated in these locations; however, the focus groups enabled us to explore participants' diverse perceptions of regional food systems. The store intercept-survey also illuminates some of the qualitative findings. We limited our study to the U.S. Northeast, which may have regional characteristics (e.g., the small size of many of the states and their close proximity) that further limit applicability of these findings to other regions. Furthermore, regional food-system thinking remains a work in progress. Despite our careful intentions and deliberate research inquiry, even we still succumbed at times to the conflation of local and regional. This paper, we hope, has succeeded in clarifying these concepts in ways that can and will support regional work on food systems throughout the Northeast U.S. and beyond.

\section{Acknowledgements}

The authors gratefully acknowledge the contributions of Ronak Davé and Eliza Davenport Whiteman.

\section{References}

Adams, D. C., \& Salois, M. J. (2010). Local versus organic: A turn in consumer preferences and willingness-to-pay. Renewable Agriculture and Food Systems, 25(4), 331-341. http://dx.doi.org/10.1017/S1742170510000219

Amin, A. (2004). Regions unbound: Towards a new politics of place. Geografiska annaler: Series B, Human Geography, 86(1), 33-44. http://dx.doi.org/10.1111/j.0435-3684.2004.00152.x

Barham, E. (2003). Translating terroir: The global challenge of French AOC labeling. Journal of Rural Studies, 19 (1), $127-$ 138. http://dx.doi.org/10.1016/S0743-0167(02)00052-9

Barham, E., Bingen, J., \& Hinrichs, C. C. (2011). Geographical indications in the United States. In E. Barham \& B. Sylvander (Eds.), Geographical indications for food: Local development, global recognition (pp. 122-137). Oxford, UK: CABI.

Barnett, C., Clarke, N., Cloke, P., \& Malpass, A. (2005). The political ethics of consumerism: Citizenship between individualisation and participation. Consumer Policy Review, 15(2), 45-51. Retrieved from http://oro.open.ac.uk/7143/1/CPR Paper.pdf

Bonanno, A., Chenarides, L., \& Lee, R. (2015, June). Assessing the healthfulness of food purchases among low-income area shoppers in the Northeast. Paper presented at the 2015 NAREA/CAES Joint Annual Meeting, Newport, RI.

Born, B., \& Purcell, M. (2006). Avoiding the local trap: Scale and food systems in planning research. Journal of Planning Education and Research, 26(2), 195-207. http://dx.doi.org/10.1177/0739456X06291389

Bostrom, M. (2005). Digesting public opinion: A meta-analysis of attitudes toward food, health and farms. Washington, DC: Frameworks Institute. Retrieved from www.frameworksinstitute.org/assets/files/PDF_FoodSystems/food_systems_meta_analysis.pdf

Braun, V., \& Clarke, V. (2006). Using thematic analysis in psychology. Qualitative Research in Psychology, 3(2), 77-101. http://dx.doi.org/10.1191/1478088706qp063oa

Clancy, K., Bonanno, A., Canning, P., Cleary, R., Conrad, Z., Fleisher, D., Gómez, M., Griffin, T., Lee, R., Kane, D., Palmer, A., Park, K., Peters, C., \& Tichenor, N. (2017). Using a market basket to explore regional food systems. Journal of Agriculture, Food Systems and Community Development, 7(4), 163-178. https://doi.org/10.5304/jafscd.2017.074.018 
Clark, J. K., \& Inwood, S. M. (2016). Scaling-up regional fruit and vegetable distribution: Potential for adaptive change in the food system. Agriculture and Human Values, 33(3), 503-519. http://dx.doi.org/10.1007/s10460-015-9618-7

Darby, K., Batte, M. T., Ernst, S., \& Roe, B. (2008). Decomposing local: A conjoint analysis of locally produced foods. American Journal of Agricultural Economics, 90(2), 476-486. http://dx.doi.org/10.1111/j.1467-8276.2007.01111.x

Dumont, A., Davis, D., Wascalus, J., Wilson, T.C., Barham, J., \& Tropp, D. (2017). Harvesting opportunity: The power of regional food system investments to transform communities. St. Louis, MO \& Washington, DC: Federal Reserve Bank of St. Louis, Board of Governors of the Federal Reserve System. Retrieved from https://www.stlouisfed.org/communitydevelopment/publications/harvesting-opportunity

DuPuis, E. M., \& Goodman, D. (2005). Should we go "home" to eat?: Toward a reflexive politics of localism. Journal of Rural Studies, 21(3), 359-371. http://dx.doi.org/10.1016/j.jrurstud.2005.05.011

Eriksen, S. N. (2013). Defining local food: Constructing a new taxonomy-three domains of proximity. Acta Agriculturae Scandinavica, Section B-Soil \& Plant Science, 63(sup1), 47-55. http://dx.doi.org/10.1080/09064710.2013.789123

Feldmann, C., \& Hamm, U. (2015). Consumers' perceptions and preferences for local food: A review. Food Quality and Preference, 40, 152-164. http://dx.doi.org/10.1016/i.foodqual.2014.09.014

Fitch, C., \& Santo, R. (2016). Instituting change: An overview of institutional food procurement and recommendations for improvement (Research Report). Baltimore, MD: Johns Hopkins Center for a Livable Future. Retrieved from https://www.jhsph.edu/research/centers-and-institutes/johns-hopkins-center-for-a-livablefuture/research/clf publications/pub rep desc/instituting-change.html

Gillespie, G., Hilchey, D., Hinrichs, C. \& Feenstra, G. (2007). Farmers' markets as keystones in rebuilding local and regional food systems. In C. Hinrichs \& T. Lyson (Eds.), Remaking the North American food system: Strategies for sustainability (pp. 65-83). Lincoln, NE: University of Nebraska Press.

Giovannucci, D., Barham, E., \& Pirog, R. (2010). Defining and marketing “local” foods: Geographical indications for U.S. products. The Journal of World Intellectual Property, 13(2), 94-120. http://dx.doi.org/10.1111/j.17471796.2009.00370.x

Greene, E. A., LaMotte, A. E., Cullinan, K., \& Smith, E. R. (2005). Ground-water vulnerability to nitrate contamination in the Mid-Atlantic region (USGS Fact Sheet FS 2004-3067). Reston, VA: U.S. Geological Survey. Retrieved from https://pubs.usgs.gov/fs/old.2004/3067/

Grunert, K. G., Hieke, S., \& Wills, J. (2014). Sustainability labels on food products: Consumer motivation, understanding and use. Food Policy, 44, 177-189. http://dx.doi.org/10.1016/j.foodpol.2013.12.001

Harris, G., Nixon, D., Newman, L., \& Mullinix, K. (2016). Delineating the Southwest British Columbia bioregion for food system design and planning: A practical approach. Journal of Agriculture, Food Systems, and Community Development, 6(4), 71-86. http://dx.doi.org/10.5304/jafscd.2016.064.010

Hedden, W. P. (1929). How great cities are fed. Boston, MA: D. C. Heath.

Hilchey, D. (2008). "Goût de terroir: Exploring the boundaries of specialty agricultural landscapes." In C. Goetcheus \& E. MacDonald (Eds.), Preserving the boundaries of historic landscape preservation (pp. 56-71). Clemson, SC: Clemson University Digital Press.

Hilchey, D., Gillespie, G., \& Henehan, B. (2006). Small-scale grower cooperatives in the Northeast United States: A study of organizational characteristics, manager, member and director attitudes, and the potential for improving regional inter-cooperative collaboration (RBS Research Report 210). Washington, DC: U.S. Department of Agriculture Rural DevelopmentCooperative Programs. Retrieved from http://www.rd.usda.gov/files/RR210.pdf

Hinrichs, C. (2016). Fixing food with ideas of "local” and "place." Journal of Environmental Studies and Sciences, 6(4), 759764. http://dx.doi.org/10.1007/s13412-015-0266-4

Hinrichs, C., \& Charles, L. (2012). Local food systems and networks in the US and the UK: Community development considerations for rural areas. In M. Shucksmith, D. L. Brown, S. Shortall, J. Vergunst \& M. E. Warner (Eds.), Rural Transformations and Rural Policies in the UK and US (pp.156-176). New York \& Abingdon, UK: Routledge, Taylor \& Francis.

Horst, M., \& Gaolach, B. (2014). The potential of local food systems in North America: A review of foodshed analyses. Renewable Agriculture and Food Systems, 1-9. http://dx.doi.org/10.1017/S1742170514000271 
Howard, P. H., \& Allen, P. (2010). Beyond organic and fair trade? An analysis of ecolabel preferences in the United States. Rural Sociology, 75(2), 244-269. http://dx.doi.org/10.1111/j.1549-0831.2009.00009.x

Hu, W., Batte, M. T., Woods, T., \& Ernst, S. (2012). Consumer preferences for local production and other value-added label claims for a processed food product. European Review of Agricultural Economics, 39(3), 489-510. http://dx.doi.org/10.1093/erae/ibr039

Ilbery, B., \& Kneafsey, M. (2000). Registering regional specialty food and drink products in the United Kingdom: The case of PDOs and PGIs. Area, 32(3), 317-325. http://dx.doi.org/10.1111/j.1475-4762.2000.tb00144.x

Jensen, J. (2010). Local and regional food systems for rural futures (RUPRI Rural Futures Lab Foundation Paper No. 1). Iowa City, IA: University of Iowa College of Public Health, Rural Policy Research Institute.

Jones, M. (2009). Phase space: Geography, relational thinking, and beyond. Progress in Human Geography, 33(4), 487-506. http://dx.doi.org/10.1177/0309132508101599

Kirschenmann, F., Stevenson, S., Buttel, F., Lyson, T., \& Duffy, M. (2008). Why worry about the agriculture of the middle? In T. A. Lyson, G. W. Stevenson, \& R. Welsh (Eds.), Food and the mid-level farm: Renewing an agriculture of the middle (pp. 3-22). Cambridge, MA: MIT Press.

Kloppenburg, J. R., Hendrickson, J., \& Stevenson, G. W. (1996). Coming into the foodshed. Agriculture and Human Values, 13(3), 33-42. http://dx.doi.org/10.1007/BF01538225

Kneafsey, M. (2010). The region in food-important or irrelevant? Cambridge Journal of Regions, Economy and Society, 3(2), 177-190. http://dx.doi.org/10.1093/cjres/rsq012

Kremer, P., \& Schreuder, Y. (2012). The feasibility of regional food systems in metropolitan areas: An investigation of Philadelphia's foodshed. Journal of Agriculture, Food Systems, and Community Development, 2(2), 171-191. http://dx.doi.org/10.5304/jafscd.2012.022.005

Kuznesof, S., Tregear, A., \& Moxey, A. (1997). Regional foods: A consumer perspective. British Food Journal, $99(6), 199$ 206. http://dx.doi.org/10.1108/00070709710181531

Low, S. A., Adalja, A., Beaulieu, E., Key, N., Martinez, S., Melton, A., ... Jablonski, B. B. R. (2015). Trends in U.S. local and regional food systems (Administrative Pub. No. 68). Washington, DC: U.S. Department of Agriculture, Economic Research Service. Retrieved from http://www.ers.usda.gov/webdocs/publications/42805/51173 ap068.pdf.v $=42083$

Martinez, M., Hand, M., Da Pra, M., Pollack, S., Ralston, K., Smith, T., .. Newman, C. (2010). Local food systems: concepts, impacts, and issues (ERR-97). Washington, DC: U.S. Department of Agriculture, Economic Research Service.

Retrieved from https://www.ers.usda.gov/publications/pub-details/?pubid $=46395$

Massey, D. B. (2005). For space. London, UK \& Thousand Oaks, CA: SAGE.

McFadden, D. T. (2015). What do we mean by "local foods"? Choices, 30(1), 1-6. http://choicesmagazine.org/choicesmagazine/theme-articles/community-economics-of-local-foods/what-do-we-mean-by-local-foods

McKinney, M. J. \& Johnson, S. (2009). Working across boundaries: People, nature and regions. Cambridge, MA: Lincoln Institute of Land Policy.

Morgan, K., Marsden, T., \& Murdoch, J. (2006). Worlds of food: Place, power, and provenance in the food chain. Oxford, UK \& New York, NY: Oxford University Press.

Mount, P. (2012). Growing local food: Scale and local food systems governance. Agriculture and Human Values, 29(1), 107-121. http://dx.doi.org/10.1007/s10460-011-9331-0

Newman, L., \& Dale, A. (2009). Large footprints in a small world: Toward a macroeconomics of scale. Sustainability: Science, Practice, \& Policy, 5(1). http://dx.doi.org/10.1080/15487733.2009.11908024

Onozaka, Y., Nurse, G., \& McFadden, D. T. (2010). Local food consumers: How motivations and perceptions translate to buying behavior. Choices, 25(1), 1-6. http://www.jstor.org/stable/choices.25.issue-1

Peters, C., Bills, N. L., Wilkins, J. L., \& Fick, G. W. (2008). Foodshed analysis and its relevance to sustainability. Renewable Agriculture and Food systems, 24(1), 1-7. http://dx.doi.org/10.1017/S1742170508002433

Ponte, S. (2016). Convention theory in the Anglophone agro-food literature: Past, present and future. Journal of Rural Studies, 44(4), 12-23. http://dx.doi.org/10.1016/j.jrurstud.2015.12.019 
Ruhf, K., \& Clancy, K. (2010). It takes a region... Exploring a regional food systems approach (Working Paper). Kingston, NY: Northeast Sustainable Agriculture Working Group. Retrieved from http://nesawg.org/sites/default/files/NESAWGRegionalFoodSystemFINALSept2010.pdf

Saberi, H. (2016, May). Stuck in the middle with you: Peri-urban areas in the food system [Blog post]. Baltimore, MD: Johns Hopkins Center for a Livable Future. Retrieved from http://livablefutureblog.com/2016/05/stuck-in-the-middlewith-you-peri-urban-areas-and-the-food-system\#more-10966

Sonnino, R. (2007). The power of place: Embeddedness and local food systems in Italy and the UK. Anthropology of Food [Online], S2. http://aof.revues.org/454

Sonnino, R., Marsden, T., \& Moragues-Faus, A. (2016). Relationalities and convergences in food security narratives: Towards a place-based approach. Transactions of the Institute of British Geographers, 41(4), 477-489. http://dx.doi.org/10.1111/tran.12137

Thornton, P. K., Ericksen, P. J., Herrero, M., \& Challinor, A. J. (2014). Climate variability and vulnerability to climate change: A review. Global Change Biology, 20(11), 3313-3328. http://dx.doi.org/10.1111/gcb.12581

Tregear, A., Arfini, F., Belletti, G., \& Marescotti, A. (2007). Regional foods and rural development: The role of product qualification. Journal of Rural Studies, 23(1), 12-22. http://dx.doi.org/10.1016/j.jrurstud.2006.09.010

U.S. Department of Commerce, Economics and Statistics Administration, U.S. Census Bureau. (n.d.). Census regions and divisions of the United States. Washington, DC: Author. Retrieved from http://www2.census.gov/geo/pdfs/mapsdata/maps/reference/us regdiv.pdf

Zippert, J. (2014). Federation of Southern Cooperatives/Land Assistance Fund works to end poverty and start social justice in the rural South [Email Newsletter]. Grassroots Economic Organizing [GEO] Newsletter, 2(18). Retrieved from http://geo.coop/story/federation-southern-cooperativesland-assistance-fund-works-end-poverty-and-start-social 